may be one of many and will inevitably attain its three score and ten ; terminating in labour and sorrow. But there must come a lejuvenation, and the rejuvenation, possibly, may one day be pondered by other Minds than ours. Remember that after some ten thousand millions of years there still survives 50 per cent. of the heat-generating elements, and the effect of their diminution is only to lengthen out the recurring geological ages. Our planetary companions may be in various stages of such cyclical changes.

\title{
Recovery of Hughes's Original Microphones and Other Instruments of Historic Interest.
}

\section{By A. A. Campbell Swinton, F.R.S.}

GROM the perusal of David Hughes's note-books recently bequeathed to the British Museum by Mrs. Hughes, and sent to me for examination by the Keeper of the Manuscripts (see Nature, March 9, r922, pp. $\left.3^{1} 5^{-} 3^{I} 6\right)$, it became obvious to me that Hughes must at one time have possessed numerous original instruments, mostly constructed with his own hands. Having been informed that the note-books had been rescued from "an incredible accumulation of useless lumber," it occurred to me to try to locate this "lumber" if still existent, and to see whether it comprised any of the instruments. To make a long story short, a room in a furniture depository not far from the Tottenham Court Road was found to be filled with Hughes's personal effects, which had been stored there since his death in I9oo, when Mrs. Hughes returned to America. Having interested Col. H. G. Lyons, F.R.S., Director of the Scjence Museum, in the matter, the effects were carefully examined, when not only were there discovered eight more note-books - one containing an illustrated account of Hughes's invention of the microphone--but also numerous instruments.

These comprise a number of microphones, of which several are different-sized instruments of the well-known pivoted-lever type. Others consist of pointed carbon pencils, loosely held at their ends between fixed carbon sockets, the whole being mounted on soundingboards, which in one case takes the form of an inverted Japanese ash-tray. Several more consist of carbon pencils suspended pendulum-wise by paper strips, so as to bridge other carbon pencils mounted on vertical sounding-boards, while others, again, consist of glass tubes containing either carbon blocks held together by a light spiral spring, or carbon granules. Finally, among the microphones, there is the one consisting of three French nails that has served to illustrate many a text-book.

In addition, there is an induction balance, probably the first one that Hughes made, together with the actual instruments with which he practised wireless telegraphy in 1879 . They are all readily identified from the illustrated descriptions in the note-books, and include the clockwork with which currents from a single-cell battery, connected to one of the coils of the induction balance, were interrupted so as to transmit wireless signals. There are also two Bell telephones, evidently made by Hughes himself, together with two more which he says were made for him by Sax, which he used for wireless reception in connection with a water-tight pocket battery, and a special microphone that seems to have acted as a selfdecohering coherer. This latter is contained in a glass bottle, the loose contact being made between a steel needle and a wire loop, which latter Hughes says he made more sensitive by coating it with soot from the flame of a spirit lamp.

With these simple pieces of home-made apparatus Hughes not only prepared the way for the modern telephone transmitter, but also transmitted and received wireless signals over distances up to 300 yards no less than 43 years ago.

All these instruments have been made over to the Science Museum, South Kensington, by Mrs. Hughes's trustees, and are now on view in Room No. Io.

\section{$\mathrm{Obit}$ u a y.}

WE learn from the British Medical Journal that Dr. Harris Graham died at Beirut, Syria, on February 27. Dr. Graham, who was in his sixtieth year, was of Canadian birth and was educated at Toronto and Michigan Universities. Going to Turkey as a missionary he served four years at Aintab Medical College. On its closure, he was called to Beirut and joined the American University there in I889. During various leaves of absence he worked in Berlin and Vienna, and advanced evidence that a Culex mosquito is the carrier of dengue fever. He had an extensive practice and spoke all the principal languages of the Levant. Dr. Graham will be much missed, for he was an energetic and inspiring teacher and a physician of great acumen.

THE Chemiker Zeitung of March 25 announces the death, at the age of eighty-four years, of Prof. A. Naumann. Prof. Naumann was one of the first workers in the field of what is now called physical chemistry. His researches on dissociation, thermochemistry, and mass action, and his text-book had great influence on the science; his name is prominent in all the earlier work in this field.

THE death is announced, at the age of fifty-one years, of Dr. George Vincent Wendell, who had occupied a chair of physics at Columbia University since r9ıo. From I 892 to 1907 he held various posts at the Massachusetts Institute of Technology, and from 1907 to Igro he was professor of physics and head of the department at the Stevens Institute of Technology, New Jersey.

WE deeply regret to record the death on April 9, at seventy-seven years of age, of Sir Patrick Manson, G.C.M.G., F.R.S., whose pioneer work on tropical diseases opened up fields of research of profound significance both to science and civilisation. 